\title{
Psycholinguistic Predictors of Health
}

\section{Психолінгвістичні предиктори здоров'я}

\section{Serhii Maksymenko ${ }^{1}$}

Dr. in Psychology, Professor, Academician, Director of

G.S. Kostiuk Institute of Psychology of the National Academy of Pedagogical Sciences of Ukraine orcid.org/0000-0002-3592-4196 Researcher ID: A-9398-2015

\section{Maryna Orap ${ }^{2}$}

Ph.D. in Psychology, Associate Professor

\section{Сергій Максименко ${ }^{1}$} доктор психологічних наук, професор, академік НАПН України, директор Інституту психології ім. Г.С. Костюка НАПН України

\section{E-mail: orap2003@ukr.net orcid.org/0000-0001-7598-8453}

${ }^{1}$ G.S. Kostiuk Institute of Psychology of the National Academy of Educational Sciences of Ukraine $\triangle$ 2, Pankivska Str., Kyiv, Ukraine, 01033

${ }^{2}$ Ternopil Volodymyr Hnatyuk National Pedagogical University 2, M. Kryvonosa Str., Ternopil, Ukraine, 46027

\section{Марина Орап ${ }^{2}$}

доктор психологічних наук, доцент

\author{
${ }^{1}$ Інститут психології \\ імені Г.С. Костюка НАПН Украӥни \\ $\checkmark$ вул. Панківська, 2, м. Київ, \\ Україна, 01033
}

Original manuscript received February 14, 2018

Revised manuscript accepted September 15, 2018 


\section{ABSTRACT}

The article deals with the actual issues of psycholinguistics, which are related to the preservation and restoration of human health. The main research directions research of psychology of health are determined and the theoretical preconditions of psycholinguistic aspects of health are analyzed. Researches in cognitive-behavioral and positive psychotherapy makes it possible to determine that the spoken words directly affect the state of person's health. The lack of detailed empirical studies motivated us to this study, which was intended to determine the qualitative differences in the speech production of healthy and sick people. The hypothesis of the empirical study was that there are common sense traits of the narrative that unite people with a medical diagnosis. The hypothesis verification was carried out with the help of psycholinguistic techniques, in particular, the autonarrative "My Life" and the method "Psychological Autobiography". The sample was composed from oncologic patients and healthy people, students of univercities. After analysis and interpretation of the results of the study, it was found that differences in speech experience and the implementation of speech activity of healthy and sick people are in the qualitative characteristics of the subjective evaluation of the components of the internal picture of life, manifested through the analysis of the syntagmatic composition of the narrative. Common narratives that combine the speech activity of sick people are: 1) increase the proportion of words with negative emotional coloring on the assessment of their own lives; 2) increase the proportion of "affective" words on the designation of the somatic and personal components of the internal picture of life; 3) the presence of syntagmas describing autoaggression and retroflection. The study shows the correlations between the peculiarities of speech experience and the state of health of respondents. So, in this perspective psycholinguistics of health determine the laws of the influence of personality's speech on the state of his mental, social and physical health as the main subject of its studies.

Key words: psycholinguistics, health, narrative, internal picture of life, syntagmatic structure, autoaggression.

\section{Вступ}

Сучасні психологічні дослідження розглядають здоров'я у найбільш загальному вигляді як благополуччя (wellbeing), як відносно стійкий стан, у якому особистість добре адаптована, зберігає інтерес до життя i досягає самореалізації. За такого підходу проблема здоров'я перестає бути проблемою хворих людей, а стає перспективою здорових людей стати щасливими. Як зазначав Ш. Тейлор, «дослідження в галузі біхевіористичної медицини i, 
відповідно, в психології здоров'я прийшли до розуміння того, що біологічні, психологічні та соціальні фактори причетні на всіх етапах здоров'я та хвороби» (Taylor, 1990). I у першому підручнику з психології здоров'я, що 1986 року випустив Ш. Тейлор зазначено, ця галузь психології вивчає вплив психологічних чинників на спроможність людей залишатися здоровими, окреслює їх значення в появі хвороб, а також їхню роль у формуванні поведінки людей під час хвороби. Накопичення знань сприяло зміні парадигми вивчення здоров'я. I сьогодні здоров'я розглядається як надбання біопсихофізичного організму, основним критерієм чого є повноцінне комфортне життєздійснення (Ананьев, 1998; Bourne, 2010; Keefe, 2011; Maksymenko, Yevtukh, Tsekhmister, Maksymenko \& Lazurenko, 2012). Відтак, термін здоров'я трактується Всесвітньої організацією охорони здоров'я як стан повного фізичного, психічного i соціального благополуччя, а не лише як відсутність хвороб або фізичних дефектів.

Таким чином, основні напрямки вивчення у психології здоров'я згруповані навколо проблем: 1) ролі та особливостей впливу психологічних факторів у збереженні, укріпленні і розвитку здоров’я (Засєкіна, 2012; Коцан, Ложкін \& Мушкевич, 2011; Пезешкиан, 2006; Maksymenko, 2015; Matarazzo, 1984); 2) визначення особливостей внутрішньої картини здоров'я (Ананьев, 1998; Bourne, 2010; Taylor, 1990); 3) методи психологічного впливу в укріпленні і розвитку здорової особистості (Пезешкиан, 2006; Beck, 1993; Keefe, 2011; Maksymenko, 2007).

Оскільки складовими комплексного феномену здоров'я людини є iï фізичне, соціальне і психічне здоров'я, ми можемо стверджувати, що з психолінгвістичної точки зору всі ці складові здоров’я формулюються, втілюються у слова, висловлювання, тексти, у наративи та зміст внутрішнього діалогу людини. А відтак, ігнорувати аспект впливу наших думок, оформлених у слова, на стан рівноваги, стійкості та гармонії, який $є$ основою здоров'я, неможливо. Тому, незалежно від парадигми дослідження, мовлення розглядається засобом, що впливає на здоров'я через вплив на внутрішню картину життя та життєвий шлях людини.

Найбільш близько до роботи із словесним вираженням думок підійшла когнітивно-поведінкова терапія (Beck, 1976; Ellis, 1974), 
котра ставить якість і суб'єктивне задоволення життям особистості у пряму залежність від iї автоматичних думок (звісно, виражених вербально). Автоматична думка - перша думка, яка виникає як реакція на певний емоціогенний подразник визнається потужним джерелом інтерпретації життєвих ситуацій, а відтак - і побудови життєвих сценаріїв у широкому смислі. Відтак, як доводить когнітивно-поведінкова терапія, змінюючи наші автоматичні думки, а слідом за ними і глибинні переконання - ми можемо змінювати і свій суб'єктивний стан задоволення життям. А отже впливати на здоров'я.

Цінною у цьому плані $є$ позиція позитивної психотерапії, яка зазначає, що для цілого ряду хвороб не виявлена точна, науково обгрунтована причина анатомо-фізіологічного характеру, їх названо «ендогенними» і визнано переважаючий вплив саме соціопсихологічних факторів на їх виникнення. Тут слід зупинитись на відомих поглядах німецького психотерапевта іранського походження, Носсрата Пезешкіана, котрий одужання пацієнта ставить у пряму залежність від слів, які той вживає. Автор зазначає, що саме використання слів, які ми вважаємо вдалими метафорами, на кшталт - «Мені перекрили кисень» або «Це не дає мені дихати» напряму здійснюють програмування людини на хворобу (Пезешкиан, 2006). Таке мовлення лікар Пезешкіан називає «органічним мовленням» у смислі - «мимовільне», «спонтанне», некероване. I стверджує, що корекція власної мовленнєвої діяльності значно покращує стан здоров'я людини. Цікавим питанням, що викликало жваву наукову дискусію стало питання про те, чи органічне мовлення створює, провокує розвиток хвороби, чи, можливо, просто сигналізує про неї. Тобто, слова органічного мовлення - це причина чи наслідок хвороби? Однієї обгрунтованої відповіді на це питання поки що немає, але це спричинило розвиток психологічних, психолінгвістичних і психотерапевтичних досліджень у двох напрямках. Один напрямок (переважаючий) присвячений тому, які особливості мовлення вказують на наявність певних проблем у здоров'ї. Зокрема, значимими є дослідження D. Rubin, A. Boals та K. Klein (Rubin, Boals \& Klein, 2010) про взаємозв'язок лексичних особливостей наративів та сприймання травматичної особистої події, також S.D. Moore та L.R. Brody (Moore \& Brody, 2009) про 
лінгвістичні предиктори самоусвідомлення у самонаративах. Другий напрямок представлений дослідженнями того, слова на позначення яких саме емоцій є переважаючими та більш вагомими у мовленні респондентів, та як саме це впливає на самопочуття та перебіг лікування. Більшість дослідників сходяться у думці про те, що негативні сторони об'єкта, події є більш вагомими, ніж позитивні аспекти суджень (Kahneman \& Tversky, 1982; Peeters \& Czapinski, 1990). Відтак, слова, що позначають негативні емоції (стосовно людей, подій і об'єктів) спричиняють сильнішу емоційну реакцію, ніж позитивно спрямовані слова, а отже, є більш значимими у мовленнєвому досвіді респондентів. Водночас, дослідженням (Lacetti, 2007) виявлено статистично значущі кореляції між словами, на позначення позитивних емоцій та емоційним самопочуттям жінок, хворих на рак молочної залози. Саме тому, подальші дослідження стосувались проблем ролі мовлення у процесі одужання. Дослідженнями (Martino, Onorato \& Freda, 2015) виявлено, що експресивне письмо дає змогу жінкам, хворим на рак молочної залози можливість реорганізувати емоційну травму, отриману внаслідок хвороби.

Визнаючи мовлення засобом формування i оформлення думок (а отже - i всіх бажань, мрій, установок і таке інше), психолінгвістика створює передумови для глибоко дослідження ролі мовленнєвої діяльності у формуванні і збереженні людського здоров'я. У даному напрямі актуальним $є$ дослідження Л.В. Засєкіної, яка виявила залежність здоров'я особистості від наративного досвіду та роль останнього у реорганізації травмуючого досвіду особистості (Засєкіна, 2012). Якщо продовжити дані дослідження у широкому полі - на весь мовленнєвий досвід - то ми зможемо означити закономірності організації та змісту мовленнєвого досвіду, які сприяють оптимізації здоров'я людини. У такому аспекті аналітичний синтез основних ідей когнітивної і дискурсивної парадигм відкриває способи для розв'язання завдань психолінгвістики здоров'я. Ми думаємо, що точкою, у якій найбільш точно і глибоко перетинаються психологія здоров'я і психолінгвістика $\epsilon$ власне психологічна герменевтика, а точніше - наративна психологія. За влучним висловом Л.В. Засєкіної, «психологічна герменевтика 
допомагає нам зрозуміти поняття наративу як осмисленої лінії життя особистості, а психолінгвістика надає конкретний діагностичний інструментарій для його вивчення».

Аналіз літератури продемонстрував, що сучасні дослідження розглядають особистість як суб'єкт психолінгвістичного впливу тобто як продуцента текстів (Калмикова, Калмиков, Лапшина \& Харченко, 2008; Орап, 2016; Carroll, 1999; Osgood, 1998; Maksymenko \& Serdiuk, 2016). Тому традиційно психолінгвістика представляє діагностичний інструментарій для аналізу суб'єктивної картини світу хворого, для визначення його ставлення до хвороби тощо.

Відтак, недостатньо дослідженим $є$ аспект особистості як об'єкта психолінгвістичного впливу. У даному напрямку зустрічаємо лише роботи, спрямовані на дослідження факторів, ролі, впливу, особливостей тощо психологічного впливу на особистість хворої людини для ii одужання. Але не зустрічаємо досліджень, котрі розглядають вплив смислів і текстів, котрі продукує особистість, в першу чергу, на неї саму. Чи можливо говорити про те, що слова можуть не лише сигналізувати і виявляти недугу, але і бути чинниками хвороб? Відповідь на це питання дає змогу означити новий напрям у розвитку теоретичного i практичного доробку психолінгвістичної науки. У такому аспекті дослідження слід спрямувати на: 1) вияв слів-маркерів хвороби; 2) вивчення слів чинників здоров'я, слів, що створюють позитивне налаштування, баланс і рівновагу.

Найбільш глобальне практичне завдання - створення діагностики можливих захворювань за аналізом мовлення особистості. Це вимагає розв'язання численних часткових завдань, в тому числі й теоретичних. Відтак, метою даного дослідження $є$ визначення особливостей мовленнєвої діяльності, що корелюють із станом здоров'я людини. Загальною гіпотезою є уявлення про те, що словесне оформлення автоматичних думок може слугувати сигналом соматичних захворювань. Для розв'язання цієї мети слід визначити якісні відмінності у мовленнєвій продукції здорових і хворих людей, що й спричинило формулювання гіпотези емпіричного дослідження про те, що існують спільні змістові ознаки наративу, котрі об'єднують людей із медичним діагнозом. 


\section{Методи та методики дослідження}

Для перевірки висунутої гіпотези у емпіричній частині дослідження ми послуговувались наративними методиками, зокрема використовували написання респондентами наративу «Моє життя». Методика «Психологічна автобіографія», розроблена українською дослідницею О.Ю. Коржовою, призначена для оцінки переживань, пов'язаних 3 найбільш значимими сферами життєдіяльності людини, дає змогу виявити значущі події, їх оцінки та емоції, викликані цими подіями (Коржова, 1994).

\section{Результати та дискусії}

У емпіричному дослідженні взяло участь 123 респонденти. 3 них 56 людей із медичним діагнозом та 67 здорових людей. Вибірку склали пацієнти Тернопільського обласного онкологічного диспансеру та Національного Інститут раку в Києві. Середній вік - 42 роки. Умовно названа «Пацієнти». Вибірка «здорові» це студенти факультету післядипломної освіти Тернопільського національного університету імені Володимира Гнатюка, середній вік 38 років. Умовно названа «Студенти».

Емпіричне дослідження здійснювалось у кілька етапів.

На першому етапі за допомогою методики «Психологічна автобіографія» ми виявили основні травматичні події, які потенційно могли спровокувати хворобу. При аналізі результатів діагностики до уваги брались змістові та емоційні характеристики зазначених у автобіографії подій.

На цьому етапі виявлено таку тенденцію. Психологічна автобіографія хворих людей характеризується більшою кількістю негативних подій, як минулих, так і очікуваних, та їх більш полярною оцінкою (оцінки коливались від -5 до +5 , тоді як у здорових - групувались навколо 0). Важливими виявились результати порівняння емоційних оцінок одних і тих самих подій респондентами обох вибірок. Ми визначили спільні події (як позитивно, так і негативно оцінені) і порівняли їх оцінки у різних респондентів. Для адекватного порівняння, ми переводили оцінки у бали, а потім у процентилі окремо по позитивно і окремо по негативно оцінених подіях. Чим вища оцінка - тим більший бал. Це дало змогу виявити середню інтенсивність емоцій по вибірках при оцінці різних подій, що відображено у таблиці 1. 
Таблиця 1. Середня інтенсивність емоційної реакції у вибірці

\begin{tabular}{|c|c|c|c|}
\hline \multicolumn{2}{|c|}{ Позитивно оцінені події } & \multicolumn{2}{|c|}{ Негативно оцінені події } \\
\hline «Студенти» & «Пацієнти» & «Студенти» & «Пацієнти» \\
\hline 3,9 & 3,8 & 2,8 & 4,8 \\
\hline
\end{tabular}

Результати дають змогу означити тенденцію. При оцінці позитивних подій, у обох вибірках - однаковий розподіл оцінок. Відмінності $є$, але статистично не значимі. Тобто, приємні події (весілля, народження дітей, завершення школи, університету) усі респонденти оцінюють 3 однаковою інтенсивністю емоційного переживання. А от негативні оцінки - у вибірках різняться за своєю інтенсивністю. Тобто, одні й ті ж самі події (втрата роботи, розлучення, смерть рідних) респонденти у групі «Студенти» оцінюють у 2-3 бали, а у групі «Пацієнти» - у 4-5 балів. Крім того, істотним показником ми вважали загальне переважання негативно оцінених подій - тобто більше $50 \%$ від усіх зазначених подій. У кожного респондента визначалось відсоткове співвідношення позитивно та негативно оцінених подій. Порівняння кількості респондентів із переважанням негативних подій у обох вибірках наочно продемонстровано на діаграмі 1.

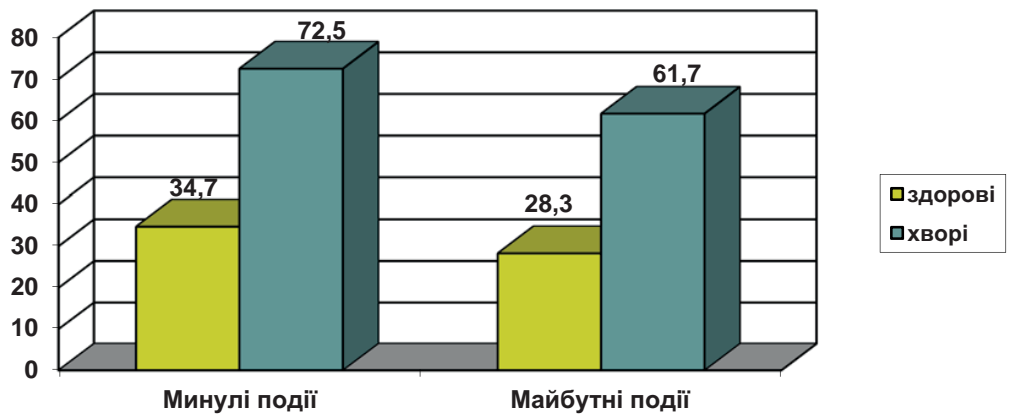

Діаграма 1. Відсоткове співвідношення респондентів із переважанням негативних подій у обох вибірках

На цьому етапі виявлено певну тенденцію. Психологічна автобіографія хворих людей характеризується більшою кількістю негативно оцінених подій як у минулому, так i у майбутньому та їх більшою поляризацією. Це дає можливість говорити про 
те, що однією 3 передумов захворювання може бути центрація особистості на негативних переживаннях, надмірна їх, так би мовити, «негативізація». Але, це могло бути пояснено, окрім іншого, i впливом травмуючого фактору у недавньому досвіді хворих - отриманий невтішний діагноз. Тому, для уточнення особливостей словесного вираження емоційного ставлення до подій, ми використали другий етап дослідження.

Наступним кроком емпіричного дослідження було створення наративу. На 2 етапі дослідження, через певний час, ми просили тих же респондентів написати ессе на тему «Моє життя». Жодних уточнюючих інструкцій надано не було. Найбільш емоційно насиченими та інформативними цілком закономірно виявились усні наративи, записані на диктофон або занотовані експериментатором.

У наративах істотними для аналізу відображення стану здоров’я ми виділили три особливості.

1. Комплексним поняттям, що охоплює цілісний образ людського буття є внутрішня картина життєвого шляху. Це відчуття, сприймання, переживання і оцінка власного життя і в результаті ставлення до життя, що є основним компонентом здоров'я. Яке, звісно, і породжує відповідні слова на його опис. Беручи до уваги зазначені компоненти внутрішньої картини життєвого шляху, ми оцінювали у наративах відображення кожного із трьох компонентів здорового життя - соматичного, особистісного і ситуаційного. Так от, у вибірці здорових людей у наративах чітко диференціюються емоції і переживання, що стосуються ситуації і особистості («Я не хотіла щуоб так сталось. Мені изе не подобалось. Але так склалось, тому щзо...»), а у хворих респондентів - емоційні переживання стосовно себе і життєвої ситуації - недиференційовані, а значить не є осмисленими та інтегрованими в досвід людини («Я в тій ситуачії опинилась через не знаю навіть щуо, я така є. Я вічно потрапляю у такі халепи. Якби я постаралась краще, то можливо, все пішло б не так...»).

2. Друга особливість стосується характеристик вживаних респондентами синтагм. D. Rubin, A. Boals та K. Klein виявили, що наративи осіб, котрі пережили чи переживають травматичну подію, розрізняються ще й за показником співвідношення «афективних» i «когнітивних» синтагм (Rubin, Boals \& Klein, 2010). Ti, хто просто 
«переживає» - вживає більше афективних слів. А вживання так званих, «когнітивних слів», під якими автори мали на увазі слова, що описують пізнавальні процеси мовця («я розумію», «я думаю», «я пам'ятаю»), відображають активний пошук мовця до розуміння стресогенної ситуації. Саме тому було підраховано кількість афективних i когнітивних синтагм у кожному наративі, до уваги бралось переважання тих чи інших слів. На діаграмі 2 показано співвідношення респондентів із відносним переважанням того чи іншого виду синтагм у наративах.

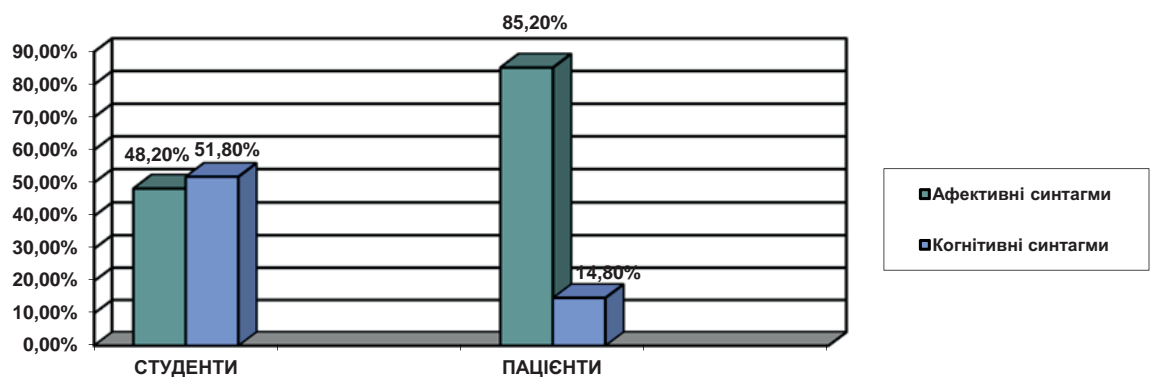

Діаграма 2. Відсоткове співвідношення респондентів із переважанням «афективних» чи «когнітивних» синтагм

Як бачимо, у вибірці «пацієнти» істотно переважають синтагми «афективного» значення. Ці дані підтверджені i результатами інтерв'ю респондентів із таким переважанням - такі люди внутрішньо змирились 3 хворобою, у них було виявлено неусвідомлене прийняття хвороби. Отже, більш конструктивним для збереження здоров'я виявляється раціональна інтерпретація подій власного життя через усвідомлене осмислення власного життя та когнітивних схем відображення дійсності.

3. Ми аналізували наративи на предмет пошуку синтагматичних конструкцій, котрі відображають негативне ставлення до себе, аутоагресію i ретрофлексію. Як зазначає Н. Пезешкіан, слова, які ми вважаємо яскравими метафорами, відображаючи наше ставлення до тіла, в результаті багаторазових повторень спричинюють зміни у відповідному органі нашого тіла (Пезешкиан, 2006). У вибірці здорових людей таких синтагм не було. У вибірці хворих людей їх значна кількість навіть дала змогу здійснити класифікацію, яка відображена у таблиці 2. 
Адже, вислови, приміром, «вони всі сиділи у мене на голові» i «виїла всі печінки» - мають різний смисл i різноспрямований емоційний підтекст.

Таблиця 2. Відсоткове співвідношення різних видів негативно спрямованих синтагматичних конструкцій

\begin{tabular}{|c|c|c|c|}
\hline Життя - 65,2\% & $\begin{array}{c}\text { Внутрішні органи - } \\
44,5 \%\end{array}$ & Голова - 23,6\% & Серце - 19,7\% \\
\hline Це мене вбивало & Не переварюю & $\begin{array}{l}\text { Я думала у мене } \\
\text { голова трісне }\end{array}$ & $\begin{array}{l}\text { Серце боліло за } \\
\text { них }\end{array}$ \\
\hline $\begin{array}{l}\text { Дитина мене } \\
\text { добиває }\end{array}$ & $\begin{array}{l}\text { В печінках мені } \\
\text { сидить }\end{array}$ & $\begin{array}{l}\text { Сиділи мені на } \\
\text { голові }\end{array}$ & $\begin{array}{l}\text { Вона не мала до } \\
\text { мене серця }\end{array}$ \\
\hline Тиснули на мене & $\begin{array}{l}\text { Причепилась до } \\
\text { мене як язва }\end{array}$ & $\begin{array}{l}\text { Прямо по голові } \\
\text { мені ходили }\end{array}$ & Як ножем по серцю \\
\hline $\begin{array}{l}\text { Загналася прямо } \\
\text { до смерті }\end{array}$ & Сита по горло & $\begin{array}{l}\text { Вже всю голову } \\
\text { зламала }\end{array}$ & Як кинджал в серце \\
\hline $\begin{array}{l}\text { Смертельно } \\
\text { змучилась }\end{array}$ & Аж знудила мене & Їздили мені по вухах & $\begin{array}{l}\text { Так пекло серце за } \\
\text { ним }\end{array}$ \\
\hline
\end{tabular}

Як бачимо, переважає група агресивних синтагм, що стосуються життя загалом (65,2\%). Такі респонденти відзначають відсутність життєвих сил, у них діагностовано відсутність чітко усвідомлених мотивів одужання. Окрім вищезазначених, у 89,3\% респондентів у мовленні зустрічаються вигуки на означення ступеня яскравості емоційної реакції, типу «Та це сказитися можна», «Мені так не жити», «Здуріти можна», які також виявляються аутоспрямованими (для порівняння «Та щоб ти сказився», «Та щоб вони всі подуріли»). Таким чином, у мовленні респондентів iз медичним діагнозом часто вживаними i навіть фіксованими $\epsilon$ висловлювання, що спрямовують негативну думку на самого мовця.

\section{Висновки}

Аналіз теоретичної літератури дав змогу виокремити нагальну наукову проблему, що пов'язана із дослідженням ролі мовленнєвого досвіду та актуальної мовленнєвої діяльності мовця у збереженні та відновленні його здоров'я. Здійснене емпіричне дослідження виявило, що відмінності мовленнєвого досвіду здорових і хворих людей полягають у якісних характеристиках суб’єктивного 
оцінювання компонентів внутрішньої картини життєвого шляху, що виявляється через аналіз синтагматичного складу наративу. Спільними ознаками наративу, що об’єднують мовленнєву діяльність хворих людей є: 1) збільшення частки слів із негативним емоційним забарвленням на оцінювання подій власного життя; 2) збільшення частки «афективних» слів на позначення соматичного та особистісного компонентів внутрішньої картини життя; 3) наявність синтагм, що описують аутоагресію i ретрофлексію. Слова, усталені синтагматичні конструкції, що використовуються мовцем, програмують не тільки певні зовнішні патерни поведінки, але i внутрішню картину способу життя, впливаючи таким чином на здоров'я. Психолінгвістика здоров'я у такому ракурсі визначає предметом свого дослідження закономірності впливу мовлення особистості на стан їі психічного, соціального та фізичного здоров'я. У такому контексті ми приходимо до ідеї про психолінгвістичну гігієну - як «чистоту» думок, як таку якість думок, що спричинює гармонізацію психічних станів людини. На нашу думку, це ї $є$ актуальними перспективами подальших досліджень, що дадуть змогу поглибити знання в цьому напрямі і загалом - визначити предмет і об’єкт психолінгвістики здоров'я як перспективного новітнього напряму розвитку психолінгвістичної науки.

\section{Література}

Ананьев, В.А. Психология здоровья - новая отрасль человекознания. Вестник психосочиальной и коррекиионно-реабилитационной работы. 1998. № 4. C. 3-18.

Засєкіна, Л.В. Наративний досвід Vis-a-Vis здоров'ю особистості. Психологічні перспективи. 2012. Вип. 1. Том 19. С. 101-110.

Калмикова, Л.О., Калмиков, Г.В., Лапшина, І.М., Харченко, Н.В. Психологія мовлення і психолінгвістика. Київ : Вид-во «Фенікс», 2008. 235 с.

Коржова, Е.Ю. Методика «Психологическая автобиография» в психодиагностике жизненных ситуаций / Под ред. Л.Ф. Бурлачука. Киев : МАУП, 1994. 109 с.

Коцан, І.Я., Ложкін, Г.В., Мушкевич, М.I. Психологія здоров'я людини. Луцьк : РВВ «Вежа», 2011. 430 с.

Пезешкиан, Н. Психосоматика и позитивная психотерапия. Москва : Институт позитивной психотерапии, 2006. 464 с.

Перре, М., Бауманн, У. Клиническая психология. Санкт-Петербург : «Питер», 2007. $947 \mathrm{c}$.

Beck, A.T. (1976). Cognitive therapy and the emotional disorders. New York : International Universities Press.

Beck, A.T. (1993). Cognitive therapy: Past, present, and future. Journal of Consulting and Clinical Psychology, 61(2), 194-198. doi.org/10.1037/0022-006X.61.2.194 
Bourne, P.A. (2010). Health measurement. Health, 2(5), 465-476. doi:10.4236/ health.2010.25070

Carroll, D.W. (1999). Psychology of Language. Pacific Grove: Books/Cole, $3^{\text {rd }}$ edn.

Ellis, A. (1974). Rational-emotive theory: Albert Ellis. In A. Burton (Ed.), Operational Theories of Personality (pp. 308-344). New York : Brunner/Mazel.

Kahneman, D., Slovic, P., \& Tversky, A. (1982). Judgment Under Uncertainty: Heuristics and Biases. New York : Cambridge University Press.

Keefe, J.F. (2011). Behavioral Medicine: a voyage to the future. Annals of Behavioral Medicine, 41(2), 141-151. doi: 10.1007/s12160-010-9239-8

Laccetti, M. (2007). Expressive writing in women with advanced breast cancer. Onco Nurs Forum, 34(5), 1019-1024. doi: 10.1188/07.ONF.1019-1024

Maksymenko, S.D. (2015). Genesis of Personality existence. Montreal, Accent Graphics Communications.

Maksymenko, S.D. (2007). Psychological nature of the personality. Kyiv: KMM.

Maksymenko, S., \& Serdiuk, L. (2016). Psychological potential of personal selfrealization. Social Welfare Interdisciplinary Approach, 6(1), 92-100. doi. org/10.21277/sw.v1i6.244

Maksymenko, S.D., Yevtukh, M.B., Tsekhmister, Y.V., Maksymenko, K.S., \& Lazurenko, O.O. (2012). Psychology and Pedagogics. Kyiv: Publishing house «Slovo».

Martino, M.L., Onorato, R., \& Freda, M.F. (2015). Linguistic markers of processing trauma Experience in Women's Written Narratives During Different Breast Cancer Phases: Implications for Clinical Interventions. Europe's Journal of Psychology, 11(4), 651-663. doi: 10.5964/ejop.v11i4.991

Matarazzo, J.D., Weiss, S., Herd, A., Miller, N.E., \& Weiss, S.M. (Eds.). (1984). Behavioral Health: A Handbook of Health Enhancement and Disease Prevention. New York : John Wiley \& Sons.

Moore, D.S., \& Brody, R.L. (2009). Linguistic Predictors of Mindfulness in Written Self-Disclosure Narratives. Language Social Psychology, 28(3), 281-296. doi: 10.1177/0261927X09335264

Orap, M. (2016). Personality's Emotional and Volitional Features in the Speech Experience. European Humanities Studies: State and Society, 3, 179-188.

Osgood, Ch.E. (1988). Psycholinguistics, Cross-Cultural Universals and Prospects. Praeger Publishers.

Peeters, G., \& Czapinski, J. (1990). Positivenegative asymmetry in evaluations: The distinction between affective and informational negativity effects. In W. Stroebe \& M. Hewstone (Eds.), European Review of Social Psychology (Vol. 1, pp. 33-60). Chichester: Wiley. doi.org/10.1080/14792779108401856

Rubin, C.D., Boals, A., \& Klein, K. (2010). Autobiographical Memories for Very Negative Events: The Effects of Thinking about and Rating Memories. Cognitive Therapy Results, 34(1), 35-48. doi.org/10.1016\%2Fj.concog.2011.03.015

Taylor, S.E. (1990). Health Psychology. The Science and the Field. American Psychologist, 45(1), 40-50. doi/10.1037/0003-066X.45.1.40

\section{References}

Ananjev, V.A. (1998). Psihologiia zdorov'a [Psychology of Health. Bulletin of psychosocial and correctional-rehabilitation work]. Vestnik psihosocialnoji korekzionno-reabilitazionnoj raboty - Bulletin of psychosocial and correctional and rehabilitation work, 4, 3-18 [in Russian]. 
Zasiekina, L.V. (2012). Naratyvnyj dosvid Vis-à-Vis zdorovju osobystosti [Narrative experience Vis-a-Vis health of person]. Psihologichni Perspectyvy - Psychological Prospect, 1(19), 101-110 [in Ukrainian].

Kalmykova, L.O., Kalmykov, G.V., Lapchyna, I.M., \& Kharchenko, N.V. (2008). Psihologiia movlennia $i$ psiholingvistyka [Psychology of speech and psycholinguistic]. Kyiv : Pheniks [in Ukrainian].

Korzhova, E.Yu. (1994). Metodika «Psihologicheskia avtobiographia» v psihodiagnostike zhiznennyh situatsii [Methodology «Psychological Autobiography» in Psychodiagnostics of Life Situations]. Kyiv: MAUP [in Russian].

Kotsan, I.Ia., Lozhkin, G.V., \& Mushkevych, M.I. (2011). Psyhologiia zdorovia liudyny [Psychology of health of the personality]. Lutsk : Vezha [in Ukrainian].

Pezechkian, N. (2006). Psichosomatika i pozitivnaia psihoterapiia. [Psychosomatics and positive psychotherapy]. Moscow: Institute Positive Psychoterapy [in Russian].

Perrez, M., \& Baumann, U. (2007). Klinicheskaia psichologiia [Clinical Psychology]. Sant Petersburg : «PITER» [in Russian].

Beck, A.T. (1976). Cognitive therapy and the emotional disorders. New York : International Universities Press.

Beck, A.T. (1993). Cognitive therapy: Past, present, and future. Journal of Consulting and Clinical Psychology, 61(2), 194-198. doi.org/10.1037/0022-006X.61.2.194

Bourne, P.A. (2010). Health measurement. Health, 2(5), 465-476 doi:10.4236/ health.2010.25070

Carroll, D.W. (1999). Psychology of Language. Pacific Grove: Books/Cole, $3^{\text {rd }}$ edn.

Ellis, A. (1974). Rational-emotive theory: Albert Ellis. In A. Burton (Ed.), Operational Theories of Personality (pp. 308-344). New York : Brunner/Mazel.

Kahneman, D., Slovic, P., \& Tversky, A. (1982). Judgment Under Uncertainty: Heuristics and Biases. New York : Cambridge University Press.

Keefe, J.F. (2011). Behavioral Medicine: a voyage to the future. Annals of Behavioral Medicine, 41(2), 141-151. doi: 10.1007/s12160-010-9239-8

Laccetti, M. (2007). Expressive writing in women with advanced breast cancer. Onco Nurs Forum, 34(5), 1019-1024. doi: 10.1188/07.ONF.1019-1024

Maksymenko, S.D. (2015). Genesis of Personality existence. Montreal, Accent Graphics Communications.

Maksymenko, S.D. (2007). Psychological nature of the personality. Kyiv: KMM.

Maksymenko, S., \& Serdiuk, L. (2016). Psychological potential of personal selfrealization. Social Welfare Interdisciplinary Approach, 6(1), 92-100. doi. org/10.21277/sw.v1i6.244

Maksymenko, S.D., Yevtukh, M.B., Tsekhmister, Y.V., Maksymenko, K.S., \& Lazurenko, O.O. (2012). Psychology and Pedagogics. Kyiv: Publishing house «Slovo».

Martino, M.L., Onorato, R., \& Freda, M.F. (2015). Linguistic markers of processing trauma Experience in Women's Written Narratives During Different Breast Cancer Phases: Implications for Clinical Interventions. Europe's Journal of Psychology, 11(4), 651-663. doi: 10.5964/ejop.v11i4.991

Matarazzo, J.D., Weiss, S., Herd, A., Miller, N.E., \& Weiss, S.M. (Eds.). (1984). Behavioral Health: A Handbook of Health Enhancement and Disease Prevention. New York : John Wiley \& Sons. 
Moore, D.S., \& Brody, R.L. (2009). Linguistic Predictors of Mindfulness in Written Self-Disclosure Narratives. Language Social Psychology, 28(3), 281-296. doi: 10.1177/0261927X09335264

Orap, M. (2016). Personality's Emotional and Volitional Features in the Speech Experience. European Humanities Studies: State and Society, 3, 179-188.

Osgood, Ch.E. (1988). Psycholinguistics, Cross-Cultural Universals and Prospects. Praeger Publishers.

Peeters, G., \& Czapinski, J. (1990). Positivenegative asymmetry in evaluations: The distinction between affective and informational negativity effects. In W. Stroebe \& M. Hewstone (Eds.), European Review of Social Psychology (Vol. 1, pp. 33-60). Chichester: Wiley. doi.org/10.1080/14792779108401856

Rubin, C.D., Boals, A., \& Klein, K. (2010). Autobiographical Memories for Very Negative Events: The Effects of Thinking about and Rating Memories. Cognitive Therapy Results, 34(1), 35-48. doi.org/10.1016\%2Fj.concog.2011.03.015

Taylor, S.E. (1990). Health Psychology. The Science and the Field. American Psychologist, 45(1), 40-50. doi/10.1037/0003-066X.45.1.40

\section{АНОТАЦІЯ}

У статmі розкрито актуальні питання психолінгвістики, які пов'язані із збереженням і відновленням здоров'я людей. Визначено основні напрями досліджень психології здоров'я і проаналізовано теоретичні передумови вивчення психолінгвістичного аспекту здоров'я. Студії у когнітивно-поведінковій та позитивній психотерапії дають змогу визначити, що слова, які вимовляє людина, безпосередньо впливають на стан ії здоров'я. Відсутність докладних емпіричних досліджень спонукала до реалізації зазначеного дослідження, яке мало на меті визначити якісні відмінності у мовленнєвій продукції здорових і хворих людей. Гіпотеза емпіричного дослідження полягала в тому, що існують спільні змістові ознаки наративу, котрі об'єднують людей із медичним діагнозом. Перевірка гіпотези здійснювалась за допомогою психолінгвістичних методик, зокрема, автонаративу "Моє життя» та методики "Психологічна автобіографія». Вибірку склали пацієнти онкологічних диспансерів та здорові люди, студенти вищих навчальних закладів. у результаті аналізу та інтерпретації результатів дослідження було виявлено, що відмінності мовленнєвого досвіду $i$ здійснення мовленнєвої діяльності здорових і хворих людей полягають у якісних характеристиках суб'єктивного оцінювання компонентів внутрішньої картини життєвого шляху, що виявляється через аналіз синтагматичного складу наративу. Спільними ознаками наративу, що об'єднують мовленнєву діяльність хворих людей $\epsilon:$ 1) збільшення частки слів із негативним емоційним забарвленням на оцінювання подій власного життя; 2) збільшення частки "афективних» слів на позначення соматичного та особистісного компонентів внутрішньої 
картини життя; 3) наявність синтагм, що описують аутоагресію $i$ ретрофлексію. Здійснене дослідження демонструє наявність кореляцій між особливостями мовленнєвого досвіду та станом здоров'я респондентів. Психолінгвістика здоров'я у такому ракурсі визначає предметом свого дослідження закономірності впливу мовлення особистості на стан ії психічного, соціального та фрізичного здоров'я.

Ключові слова: психолінгвістика, здоров'я, наратив, внутрішня картина життя, синтагматична конструкція, аутоагресія.

\section{Максименко Сергей, Орап Марина. Психолингвистические предикторы здоровья}

\section{АННОТАЦИЯ}

В статье раскрыты актуальные вопросы психолингвистики, связанные с сохранением и восстановлением здоровья людей. Определены основные направления исследований психологии здоровья и проанализированы теоретические предпосылки изучения психолингвистики здоровья. Студии в когнитивно-поведенческой и позитивной психотерапии позволяют утверждать, что слова, которые произносит человек, непосредственно влияют на состояние его здоровья. Отсутствие подробных эмпирических исследований побудило к реализации данного исследования, целью которого было определить качественные различия в речевой продукции здоровых и больных людей. Гипотеза эмпирического исследования состояла в том, что существуют общие содержательные признаки нарратива, которые объединяют людей с медицинским диагнозом. Проверка гипотезы осуществлялась с помощью психолингвистических методик, в частности, автонарратива «Моя жизнь» и методики «Психологическая автобиография». Выборку составили пациенты онкологических диспансеров и здоровые люди, студенты высиих учебных заведений. В результате анализа и интерпретации результатов исследования было выявлено, что различия речевого опыта и осуществления речевой деятельности здоровых и больных людей заключаются в качественных характеристиках субъективной оценки компонентов внутренней картины жизненного пути, проявляются через анализ синтагматического состава нарратива. общими признаками нарратива, объединяющими речевую деятельность больных людей являются: 1) увеличение доли слов с негативной эмоциональной окраской для оценки событий собственной жизни; 2) увеличение доли «аффективных» слов для обозначения соматического и личностного компонентов внутренней картины жизни; 3) наличие синтагм, описывающих аутоагрессию и 
ретрофлексию. Осуществленное исследование демонстрирует наличие корреляций между особенностями речевого опыта и состоянием здоровья респондентов. Психолингвистика здоровья в таком ракурсе определяет предметом своего исследования закономерности влияния речи личности на состояние ее психического, социального и физического здоровья.

Ключевые слова: психолингвистика, здоровье, нарратив, внутренняя картина жизни, синтагматическая конструкция, аутоагрессия. 